\title{
UPAYA PENYELESAIAN SENGKETA DELIMITASI BATAS MARITIM DI WILAYAH GREATER SUNRISE ANTARA TIMOR LESTE DAN AUSTRALIA DARI PERSPEKTIF KAJIAN HUKUM PERJANJIAN INTERNASIONAL
}

\author{
EFFORTS FOR RESOLVING THE MARITIME BOARD DELIMITATION DISPUTE IN THE \\ GREATER SUNRISE AREA BETWEEN TIMOR LESTE AND AUSTRALIA FROM THE \\ PERSPECTIVE OF THE STUDY OF INTERNATIONAL AGREEMENTS
}

\author{
Putriana Septi Nauli ${ }^{1}$, Stivani Ismawira Sinambela ${ }^{2}$ \\ Universitas Potensi Utama \\ Email: Putrianaseptinauli@gmail.com ${ }^{1}$,vani.sinambela@gmail.com²
}

\begin{abstract}
The writing of this research is based on the conflict of maritime boundary issues between Timor Leste and Australia. This paper aims to find out how to resolve maritime boundary issues between Australia and Timor Leste and what are the interests of the two countries. Conflicts between countries can occur because the territorial boundaries of a country have been violated. Maritime boundary delimitation as the implementation of determining maritime boundaries between countries. In the settlement of maritime boundary delimitation disputes between Timor Leste and Australia, there was interference by a third party, namely the Arbitration or International Court of Justice, in accordance with the provisions of the 1982 UNCLOS convention. In 2016 Timor Leste Arbitration or the International Court of Justice intervened in the settlement between Timor Leste and Australia. . Greater Sunrise is an oil field in the Timor Sea from the unequal distribution of oil resources for Timor Leste which is one of the triggers for the maritime boundary delimitation conflict. In this case the author also intends to find out in detail how the agreement or agreement made by Australia and Timor Leste in resolving the problem of maritime boundary delimitation. In this case study the author also wants to know what is the agreement between Australia and Timor Leste in the division of the Greater Sunrise area.
\end{abstract}

Keywords: International Treaties, national interest, and Greater Sunrise, 1982 UNCLOS Convention and Arbitration

\begin{abstract}
ABSTRAK
Penulisan penelitian ini berdasarkan konflik permasalahan batas laut Timor Leste dengan Australia.Tulisan ini bertujuan untuk mengetahui bagaimana penyelesaian permasalahan batas maritim antara Australia dan Timor Leste dan apa yang menjadi kepentingan kedua Negara. Konflik antar Negara dapat terjadi akibat batas-batas teritorial suatu negara telah dilanggar. Delimitasi batas maritim sebagai implementasi penentuan batas-batas wilayah laut antara negara. Dalam penyelesaian delimitasi batas maritim sengketa antara negara Timor Leste dan Australia adanya campur tangan oleh pihak ketiga yakni Arbitrase atau Mahkamah Internasional, sesuai dengan ketentuan konvensi UNCLOS 1982. Pada tahun 2016 Timor leste Arbitrase atau mahkamah Internasional turut campur tangan dalam penyelesaian antar timor Leste dan Australia. Greater Sunrise merupakan ladang minyak di Laut Timor dari pembagian hasil sumber daya minyak yang tidak merata bagi Timor Leste menjadi salah satu pemicu konflik delimitasi batas maritim. Pada kasus ini Penulis juga bermasud untuk mengetahui secara detail bagaimana perjanjian atau
\end{abstract}


kesepakatan yang dilakukan Australia dan Timor Leste dalam penyelesaian masalah delimitasi batas maritim. Dalam studi kasus ini penulis tersebut penulis juga ingin mengetahui apa yang menjadi kesepakatan Australia dan Timor Leste dalam pembagian wilayah Greater Sunrise.

Kata kunci: Perjanjian Internasional, kepentingan nasional, dan Greater Sunrise, Konvensi UNCLOS 1982 dan Arbitrase

\section{PENDAHULUAN}

\section{Latar Belakang}

Perbatasan wilayah merupakan zona yang berdampak sangat penting terhadap antar negara yang hidup bertetanggaan. Dari sudut perdamaian suatu negara yang bertetangga memiliki hubungan lintas batas yang baik yang dapat diterima oleh negara-negara yang bersangkutan. Dalam sudut pandang keamanan negara yang dapat melindungi atau mengontrol wilayahnya sendiri merupakan negara yang dapat dikatakan negara yang baik, namun bagi negara yang dikatakan gagal yaitu negara yang tidak dapat mengontrol atau melindungi negaranya sehingga penyusup atau teroris dapat masuk ke negara tersebut. Sedangkan dari sudut konflik internasional, kerap sering kali bahwa perbatasan wilayah menjadi konflik. Dari sudut konflik perbatasan internasional berkaitan dengan hubungan negara satu dengan dengan negara lain atau hubungan internasional

Hubungan Internasional merupakan Ilmu yang mempelajari tentang hubungan antara Negara satu dengan Negara lainnya. Tidak hanya satu Negara namun 2 atau 3 kelompok Negara yang saling memenuhi satu sama lain. Hubungan Internasional menganalisis teoriteori antar Negara. Hubungan Internasional bersifat sebagai jembatan untuk menjalin kerjasama antar Negara baik secara organisasi internasional, kelompok, individu dan perusahaan-perusahaan multinasonal. Hubungan internasional mencakup keamanan dan strategi kekuatan militer serta menyelesaikan masalah konflik internasional.

Negara merupakan subjek hukum internasional yang memiliki unsur kedaulatan. Dalam suatu negara harus memiliki kedaulatan. Kedaulatan merupakan kekuasaan tertinggi, ini berarti negara memiliki kekuasan penuh untuk melakukan tertorialnya pada batas wilayahnya. Menurut teritorinya kedaulatan negara terdiri dari daratan, udara serta lautan. Terkait wilayah laut tidak semua negara memiliki laut, hanya negara-negara tertentu yang memiliki wilayah laut yang berbatasan dengan daratanya.

Fungsi laut sangat berpengaruh terhadap kehidupan selain sebagai media keindahan, laut juga memiliki kaya smber daya alam baik bagi yang hidup maupun yang tidak hidup. 
Sehingga dari fungsi laut tersebut memicu adanya aturan hukum. Secara teritorinya daratan menjadi titik awal sebagai penetuan hak maritim sebuah pantai negara ${ }^{1}$. Konsep hukum Laut Internasional berdasarkan sejarah pertumbuhan laut internasional yaitu pertarungan antara kosepsi Res Communis dan Res nulluis ${ }^{2}$. Berdasarkan konsep ini berasumi bahwa penggunaa laut secara terbuka dan bebas bagi setiap orang ${ }^{3}$.

Sehingga dari konsepsi Res Communis dan Res nulluis bertolak belakang dari penggunaan laut yang bebas, karena berdasarkan teritorinya suatu negara laut merupakan wilayah. Laut merupakan batas wilayah antar negara dengan negara lain (tetangganya) yang memiliki teritori laut. Batas atau delimitation merupakan bentuk entitas terhadap suatu negara , provinsi kabupaten, hingga desa-desa terpencilnya.

Dari sejarah hukum internasional penetapan batas laut teritorial antar negara berlaku secara universal. Penentuan batas wilayah laut berdasarkan konsekuensi dan pertimbangan yang ditentukan untuk kepentingan bersama. Dalam penentuan batas wilayah laut secara internasional maka disusun perundang-undangan yang mengatur wilayah laut yang di kenal dengan Konvensi Hukum Laut 1982 ( UNCLOS atau United Convention On The Law of The Sea ) yang di tetapkan dan di sahkan di Teluk Montego pada 10 Desember 1982 yang berisikan ketentuan pembagian batas wilayah laut. Konvensi UNCLOS 1982 mengubah konsep sebelumnya yaitu konsep perairan internasional yang merupakan laut bebas, sehingga suatu negara berdasarkan kedaulatannya dapat melindungi teritori perairanya serta mendapat perlindungan secara hukum internasional. Secara garis besar konvensi UNCLOS 1982 membagi teritorial perairan menjadi 2 bagian yakni zona maritim yang berada didalam dan di luar yuridiksi nasional. Berdasarkan yuridiksi nasional zona maritime yang berada didalam batas 12 mil yang disebut laut tertorial dan di luar batas $12 \mathrm{mil}$. Di luar batas wilayah yuridiksi nasional tersebut semua negara berhak di laut bebas, termasuk menangkap ikan serta pemanfaatan sumber daya alam yang berada di laut lepas tersebut. Namun meskipun begitu antar negara di beri batas maritim antar negara (maritime boundary delimitation) guna menghindari konflik. Tujuan dari batas maritim antar negara (maritime boundary

\footnotetext{
15 Malcolm N. Shaw QC, Internasional Law, terj. Derta Sri Widowatie, Imam Baehaqi dan M. Khozim, Hukum Internasional (Bandung: Nusa Media, 2013), halaman 547

${ }^{2}$ Hasyim Djalal, Perjuangan Indonesia Di Bidang Hukum Laut, Badan Pembinaan Hukum Nasional Departemen Kehakiman (Jakarta: Binacipta, 1979), halaman 11.

${ }^{3}$ Mochtar Kusumaatmadja, Hukum Laut Internasional, Badan Pembinaan Hukum nasional Departemen Kehakiman (Bandung: Binacipta, 1986), halaman 3.
} 
delimitation) untuk menghindari adanya konflik perbatasan wilayah antar negara agar tidak merugikan antar negara dengan satu sama lainnya ${ }^{4}$.

Konvensi UNCLOS 1982 sudah di akui hampir 160 negara $^{5}$ serta 1 organisasi yaitu komunitas Eropa, namun hal ini tidak menjadi panutan untuk menyeleseaikan sengketa batas maritim antar negara. Masih ada ketentuan lain yang dapat menyelesaikan pemasalahan antar negara melalui negosiasi bilateral ( negosiasi antar negara yang bersangkutan), namun harus sesuai ketentuan dalam konvensi UNCLOS 1982. Penyelesaian sengketa batas maritim antar negara dapat dilaksanakan dengan melibatkan pihak ketiga yakni Arbitrase, Mahkamah Internasional (International Court of Justice / ICJ), ITLOS (International Tribunal for the Law of the Sea) ${ }^{6}$. Seperti Timor Leste dan Australia memilih Mahkamah Internasional untuk menyelesaikan permasalahan antar kedua negara.

Adapun yang menjadi pemicu terjadinya konflik yaitu berasal dari adanya unsur ekonomi dan politik. Konflik antar Negara dapat terjadi akibat batas-batas teritorial suatu negara telah dilanggar. Terkadang konflik antar Negara dapat dipicu adanya kesenjangan pendapat yang berbeda sehingga dapat merugikan salah satu pihak yang bersangkutan, misalnya adanya sebuah perjanjian yang telah disepakati oleh kedua belah pihak namun di pertengahan dijalankanya kesepakatan tersebut salah satu pihak melanggar perjanjian tersebut, hal ini juga dapat menyebabkan terjadinya konflik. Selain itu faktor pemicu terjadinya konflik salah satunya juga suatu daerah yang memiliki sumber potensi alam yang luar biasa namun daerah tersebut berdekatan dengan Negara tetangga sehingga Negara tetangga berasumsi daerah tersebut miliknya juga.

Menurut undang-undang ZEE (Zona Ekonomi Ekslusif) No 5 tahun 1983 menyatakan "Sumber daya alam yang terdapat di dasar laut dan tanah di bawahnya serta ruang air diatasnya harus dilindungi dan dikelolah dengan cara tepat, terarah dan bijaksana", Menurut pasal 57 UNCLOS berisikan bahwa Zona Ekonomi Eksklusif (ZEE) tidak boleh melebihi 200 mil laut dari garis pangkal dari mana lebar laut teritorial diukur. Mengingat permasalah laut timor menjadi akar konflik dimana Indonesia menolak klaim Australia di laut Timor. Namun Australia menentang hal tersebut berdasarkan titik landasan kontinen. Pada 11 Desember 1991 Indonsesia dan Australia membuat perjanjian internasional tentang

\footnotetext{
4 P. Joko Subagyo, Op. Cit, halaman 1.

${ }^{5}$ E. Doukakis, Associate Professor, National

Technical University Athens Visiting Professor, Cyprus University of Technology, EastMed Symposium, Limasol, Cyprus, 17-20/11/2014, page3,http://www.oceanography.ucy.ac.cy/eastm ed/wp-content

${ }^{6}$ Saru Arifin, Hukum Perbatasan Darat Antarnegara, (Jakarta: Sinar Grafika, 2014), halaman 79
} 
landasan kontinen di laut Timor.yang dinamakan Zona Kerjasama. Dimana berdasarkan kesepakatan kedua belah pihak, perjanjian internasional tersebut berisikan "kedua belah pihak dapat melakukan ekspolarasi bersama di wilayah laut Timor dengan hasil yang dibagi dua sama rata”. Perjanjian internasional tersebut berjalan lancar, namun pada tahun 2002 Timor Leste keluar dari kependudukan Indonesia maka perjanjian tersebut tidak berlaku lagi. Sehingga pada tanggal 20 Mei 2002 kedua negara mengadakan perjanjian internasional yang dikenal dengan JPDA (Joint Petroleum Devoloment Area) dimana isi perjanjian tersebut ialah "hasil sumber daya minyak yang dihasilkan 90\% kepada Timor Leste dan $10 \%$ kepada Australia. Perjanjian batas garis landas kontinen dikenal dengan perjanjian CMAST (Certain Maritime Agreement Timor Sea) yang disepakati oleh Australia dan Timor Leste yang berisikan mengatur kerjasama pengelolahan wilayah sumber daya alam minyak bumi dan gas bumi yang sebagian besar terletak didasar laut Timor. Namun JPDA (Joint Petroleum Development Area) melintasi batas Greater Sunrise yang telah ditetapkan. Dimana isi dari JPDA ialah sumber daya minyak yang dihasilkan $10 \%$ kepada Australia dan $90 \%$ kepada Timor Leste. Sementara diketahui $20 \%$ hasil dari Greater Sunrise memasuki JPDA. Hal ini merugikan kedua belah pihak maka membatalkan perjanjian CMAST (Certain Agreement Timor Sea), karena menurut Timor Leste dirugikan oleh Australia.

Berdasarkan uraian latar belakang tersebut, maka penulis merumuskan permasalahan tersebut sebagai berikut:

1. Bagaimana upaya penyelesaian sengketa delimitasi batas maritim di wilayah Greater Sunrise antara Timor Leste dan Australia?

\section{TINJAUAN LITERATUR}

\section{Hukum Perjanjian Internasional}

Perjanjian Internasional pada hakekatnya merupakan sumber hukum internasional dan merupakan instrument-instrument yuridik yang menampung kehendak dan persetujuan negara atau subjek hukum internasional lainnya untuk mencapai tujuan bersama. Persetujuan bersama yamg dirumuskan dalam perjanjian tersebut merupakan dasar hukum internasional untuk mengatur kegiatan negara-negara atau subjek hukum internasional lainya didunia ini. ${ }^{7}$ Dalam Pasal 2 Konvensi Wina 1969, Perjanjian Internasional adalah suatu persetujuan yang

\footnotetext{
${ }^{7}$ Boer Mauna.2003. Hukum Internasional :Pengertian dan Fungsi dalam Era Dinamika Global. Ed 1. Cet 4. Bandung : PT.Alumi. Hal 82
} 
dibuat antara negara dalam bentuk tertulis, dan diatur oleh hukum Internasional, apakah dalam instrument Tunggal atau dua atau lebih instrument yang berkaitan dan apapun nama yang diberikan padanya. ${ }^{8}$

Pengertian perjanjian internasional menurut para ahli

a. Menurut Mocthtar Kumaatmadja : Perjanjian internasional adalah perjanjian yang dibuat antar bangsa dengan maksud tujuan tertentu sehingga mengakibatkan hukum tertentu.

b. Menurut Schwarzenberger : Perjanjian international adalah suatu persetujuan antar dua atau lebih negara atau subjek hukum internasional.

c. Menurut Oppenheimer Leuterpacht : Perjanian internasional adalah suatu persetujuan yang diadakan antar negara yang menimbulkan hak dan kewajiban.

Pengertian perjanjian internasional yang dirumuskan dalam perundang-undangan

a. Berdasarkan Konvensi Wina tahun1969 pasal 2 ayat 1 ( For the purposes of the present Convention; a. "treaty"means an international agreement concluded between states in written form and governed by international law, whether embodied in a single instrument or in two more related instruments and whatever its particular designation $)^{9}$

Yang diartikan : "Suatu Persetujuan yang dibuat antara negara dalam bentuk tertulis, dan diatur oleh hukum internasional, baik yang diwujudkan dalam instrumen tunggal atau dua atau lebih instrumen yang terkait dan apapun sebutan khususnya”.

b. Berdasarkan undang-undang No.24 tahun 2000: Perjanjian Internasional adalah perjanian dalam bentuk dan nama tertentu yang diatur dalam hukum internasional yang dibuat secara tertulis serta menimbulkan hak dan kewajiban di bidang hukum publik. $^{10}$

Dalam pasal 11 konvensi Wina tahun1969 menjelaskan bahwa dalam membuat persetujuan perjanjian internasional perlu adanya penandatangan (signature) pertukaran instrument perjanjian (exchange of instrument agreement), ratifikasi (ratification, akseptasi (acceptance) pesetujuan atau aksesi (approval) atau cara-cara lain yang di perhatikan dalam pembuatan perjanjian. Berdasarkan dari pengertian perjanjian internasional, memiliki berbagai jenis perjanjian internasional targantung klarifikasi dan permasalan atau kesepakan

\footnotetext{
${ }^{8}$ Boer Mauna 2003.Hukum Internasional :Pengertian dan Fungsi dalam Era Dinamika global. ed 1. Cet 4. Bandung : PT.Alumi.hal 84

${ }^{9}$ Lihat pasal 2 ayat 1 konvensi wina 1969 tentang perjanjian internasional

${ }^{10}$ Penjelasan UU No.24 tahun 2000
} 
yang bersangkutan. Perjanjian internasional berdasarkan jumlah negara yaitu perjanjian Bilateral (dua negara) serta perjanjian Multilateral (lebih dari dua negara yang bersangkutan). Perjanjian internasional berdasarkan ruang lingkup berlakunya yaitu regional dan umum.

\section{PEMBAHASAN}

\section{A. Sejarah Hubungan Diplomatik Asutralia Dan Timor Leste}

Australia dan Timor Leste merupakan dua negara yang bertetangga yang mengacu pada bidang politik dan perdagangan yang sangat erat. Sebagai negara tetangga antara Australia dan Timor Leste, Australia turut ambil alih dalam sejarah referendumnya Timor Leste untuk merdeka dari NKRI ( Negara Kesatua Republik Indonesia) hingga menjadi negara yang berdiri sendiri dan berdaulat. Setelah Timor Leste memisahkan diri dari negara Indonesia untuk memerdekan diri sebagai negara mandiri dan sebagai negara termuda di benua Asia Tenggara sekaligus termiskin. Selain membantu pembangunan negara Timor Leste, Australia membantu pertahanan dan keamanan Timor Leste.

Sebagai negara termuda dan salah satu negara miskin di Asia, Timor Leste mendapat banyak bantuan dari Australia baik dalam bidang pembangunan dan pertahanan keamanan. Sebagai sumber mitra yang siap membantu bidang perekonomian Timor Leste, Australia siap menjadi mitra pembangunan besar-besaran untuk Timor Leste dan mendapat peringkat 147 dari 187 negara dalam konteks pembangunan Manusia oleh $\mathrm{PBB}^{11}$. Seperti pada tahun 2000-2010 diperkirakan sekitar \$760 juta Australia memberikan bantuan terhadap Timor Lorosa'e oleh presiden Jose Ramos-Horta ${ }^{12}$. Pada tahun 2013-2014 anggaran bantuan yang di berikan sekitar $\$ 106$ juta $^{13}$. Untuk meningkatkan pembangunan bidang ekonomi dan kesejahteraan kedua negara bekerja sama dan untuk memperkuat ikatan kedua negara melakukan berbagai perencanaan strategis ${ }^{14}$. Perencanaan pembangunan strategis ditujukan untuk masa depan dalam jangka panjang 2012-2030. Sebagai negara tetangga guna

\footnotetext{
${ }^{11}$ Departemen Luar Negeri dan Perdagangan - Pemerintah Australia "Arsip salinan". Diarsipkan dari versi asli pada 12 Oktober 2014. Diakses pada 8 Oktober 2014

12 Oakes, Dan (24 Juni 2010). "Strategi bantuan baru untuk membantu Timor Timur" . Zaman . Media Fairfax. Diarsipkan dariversi asli pada 27 Agustus 2015.

1. ${ }^{13}$ Departemen Luar Negeri dan Perdagangan, Timor-Leste: Ikhtisar program bantuan Australia untuk Timor-Leste, Pemerintah Australia, diarsipkan dari aslinya pada 10 Januari 2015

${ }^{14}$ Departemen Luar Negeri dan Perdagangan - Pemerintah Australia "Arsip salinan". Diarsipkan dari versi asli pada 12 Oktober 2014. Diakses pada 8 Oktober 2014
} 
mempererat ikatan pertahanan dan keamanan serta pembangunan ekonomi, kedutaan besar Australia di Timor Leste terletak di kota Dili sementara kedutaan besar Timor Leste terletak di kota Canberra ${ }^{15}$, dan konsulat Timor Lorosa'e hampir di setiap bagian Australia.

Secara garis besar kepentingan Australia terhadap Timor Leste dalam bidang keamanan maupun ekonomi bahkan di bidang politik yang cukup besar. Hal ini dapat dilihat dari Australia sangat memperhatikan isu yang terjadi di Timor Leste, dalam hal bidang keamanan Australia siap membantu Timor Leste seperti mendorong Tentaranya masuk ke Timor Leste. Dalam bidang ekonomi Australia mengincar sumber daya alam Timor Leste, dimana dilaut Timor bedasarkan eksplorasi Australia mengandung sumber minyak bumi yang dapat mendorong perekonomian Australia menjadi lebih baik kedepannya.

Keuntungan yang didapat bagi Timor Leste dari eksplorasi Laut Timor di bidang keamanan dan pertahan Timor Leste dibantu oleh Australia. Dilihat dari jangka pendek tujuan Australia dalam menjaga stabilitas keamanan dan pertahanan Timor Leste guna mendapat Eksplorasi dari laut Timor. Dilihat dari dimensi sudut Australia eksplorasi dari laut Timor yang kaya dengan sumber daya alam (minyak, gas dan mineral) mendukung memajukan perekonomian kedua negara. Australia juga berkepentingan menjaga Timor Leste tidak terpengaruh menjadi instabilitas kawasan Asia. Hal ini bertujuan untuk melindungi keamanan internal Australia dan Timor Leste mengingat kawasan kedua negara ini terhitung strategis.

Dalam jangka pendek Australia menstabilkan keamanan dan pertahanan Timor Leste guna mendapat eksplorasi laut Timior yang kaya sumber daya alamnya. Dalam jangka panjang Timor Leste dan Australia mencegah keterpurukan ekonomi, terlebih bagi Timor Leste yang terbilang merupakan negara Termuda dan termasuk negara miskin di Asia. Pertahanan ekonomi dan keamanan menjadi pondasi utama bagi Timor Leste sebagai negara termuda.

\section{B. Posisi Kasus Sengketa Batas Maritim antara Timor Leste dan Australia di Laut Timor}

Permasalahan batas maritim antara negara Timor Leste dan Australia sudah berlangsung lama. Setelah merdekanya Timor Leste dari NKRI (Negara Kesatuan Republik Indonesia) pada tahun 20 Mei 2002, tetapi tidak terlepas dari intervensi oleh

15 "Timor-Leste". Departemen Luar Negeri dan Perdagangan . Diakses pada 2 Mei 2016 
negara asing terutama negara Australia. Sehingga menimbulkan kontra atau dampak terhadap kedaulatan Timor Leste terlebih persoalan batas maritim. Dari penetuan batas laut yang diatur dalam konvensi UNCLOS 1982, kedaulatan maritim Timor Leste menjadi persengketaan. Berdasarkan yuridiksi nasional zona maritim yang berada didalam batas 12 mil yang disebut laut tertorial dan di luar batas 12 mil. Di luar batas wilayah yuridiksi nasional tersebut semua negara berhak di laut bebas, termasuk menangkap ikan serta pemanfaatan sumber daya alam yang berada di laut lepas tersebut.

Berdasarkan teritorial yang menjadi persengketaan antara Timor Leste dan Australia adalah penentuan delimitasi laut secara permanen yang di tetapkan Australia dan Timor Leste, namun faktor utama dari konflik antar kedua negara tersebut yaitu perebutan wilayah Greater Sunrise. Hal ini disebabkan dengan adanya sumber daya alam yang melimpah pada wilayah Greater Sunrise (ladang minyak dan gas )yang terbesar di Laut Timor. Menurut Australia, berdasarkan landasan benua bahwa ladang Greater Sunrise milik Australia, sedangkan berdasarkan teritori yang sah pada Konvensi Genewa tahun 1958 ladang Greater Sunrise milik Australia. Namun secara geografis letak kawasan ladang Greater Sunrise berdekatan dengan Timor Leste dan berdasarkan konvensi PBB terkait hukum laut UNCLOS 1982 yang lebih berhak terhadap kawasan ladang minyak Greater Sunrise yaitu negara Timor Leste hal ini yang menjadi pemicu awal mula terjadinya konflik. Sehingga pada Tahun 2016 mengadukan hal tersebut kepada Makhamah Arbitrase Internasional yang berada di Den Haag ${ }^{16}$. Pada tanggal 26 September 2016 Pengadilan Arbitrase Internasional (PCA) di belanda setuju untuk menangani konflik yang sudah berlangsung kurang lebih 10 tahun lamanya ${ }^{17}$.

\footnotetext{
$16 \mathrm{https} / /$ google.com/amp/s/timor-leste-minta-mahkamah-arbitrase-internasional-selesaikan-sengketa-lautdengan-australia

${ }^{17} \mathrm{http} / / /$ goggle.com/amp/s/www.bbc.com/indonesia/dunia-timor-austrlia
} 


\section{Upaya penyelesaian Delimitasi Batas Maritim antara Timor Leste dan Australia}

Sebelum Timor Leste membawa permasalahan batas maritim di kawasan ladang Greater Sunrise ke pengadilan Arbitrase Internasional (PCA) terdapat kendala yang cukup sulit untuk bernegosiasi dengan Australia di bawah penetuan konvensi UNCLOS 1982. Karena Australia memiliki peran penting dari merdekanya Timor Leste, serta bantuan ekonomi terhadap pembangunan di Timor Leste diberbagai bidang. Hal ini memberikan posisi politik penting bagi Australia secara tidak langsung. Sehingga Australia memanfaatkan peluang tersebut untuk memperluas akses minyak dan gas di ladang Greater Sunrise. Maka Australia menolak permasalahan ini dengan adanya campu tangan pihak ketiga yang tidak berpihak dan memaksa untuk bernegosiasi secara bilateral ${ }^{18}$.

Dari berbagai perundingan yang telah disepakati antara Timor Leste dan Australia dimulai sejak tahun 2002 ( Perjanjian Laut Timor), tahun 2003 ( kesepakatan penyatuan internasional Sunrise ) dan pada tahun 2006 ( Perjanjian CMAST ) dari ketiga perjanjian tersebut hanya menetapkan eksplorasi minyak dan gas namun tidak dapat menyelesaikan permasalahan batas-batas laut permanen kedua negara tersebut. Perjanjian Certain Maritime Arrangment of Timor Sea dibuat karena landasan kontinel Australia tidak sesuai dengan yang di pandang oleh Timor Leste. Sehingga pada 12 Januari 2006 Timor Leste dan Australia mengadakan pertemuan untuk menandatangani perjanjian CMAST (Treaty On Certain Maritime Arragements in the Timor Sea). Perjanjian CMAST mulai berlaku pada tanggal 23 February 2007, tujuan perjanjian ini sebagai pembagian hasil yang setara dari celah Timor serta pengembangan Greater Sunrise. Sesuai dengan kesepakatan yang telah ditandatangani Timor Leste dan Australia mendapat hasil sama rata 50\%:50\% hasil dari eskplorasi minyak Greater Sunrise selain itu juga menyepakati untuk 50 tahun kedepan tidak akan menyinggung permasalahan atas klain Celah Timor ${ }^{19}$.

Setelah kesepakatan ini berlaku tahun 2007 dengan pertukaran catatan di Dili, Timor Leste, kesepakatan ini berjalan lancar. Namun kurang lebih 5 tahun berjalan perjanjian ini, pada tahun 2012, Timor Leste memutuskan perjanjian tersebut. Alasan Timor Leste menghentikan atau memutuskan perjanjian tersebut karena Australia melakukan kecurangan yaitu dengan cara memata-matai Timor Leste. Hal ini dapat dikatakan malanggar kedaulatan negara, sebab memata-matai suatu negara dapat dikatakan melakukan penyadapan atau

\footnotetext{
${ }^{18}$ Lao hamuntuk 2018

19 RMIT ABC: Fact Check, Would Spying on East Timor by the Australian Secret Intelligence Service be Illegal.
} 
pencurian data sebuah negara, hal tersebut meerupakan pelanggaran terhadap kedaulatan Timor Leste ${ }^{20}$. Dengan hal yang dilakukan Australia tersebut menjadi alasan untuk Timor Leste melakukan pemutusan perjanjian CMAST yang di sepakati tahun 2006 tersebut. Pada tahun 2013 meminta PCA (Permanent Court of Arbritation) untuk menuntut Australia atas tindakan spionase tersebut dan meminta untuk menyetujui pembatalan perjanjian CMAST tersebut ${ }^{21}$.

Setelah melakukan berbagai perundingan negosiasi yang berkepanjangan dari tahun 2002-2016, akhirnya pada tanggal 6 maret 2018 di kantor PBB di New York Australia dan Timor Leste menanda tangani kesepakatan sebagai bentuk penyelesaian sengketa perbatasan di laut Timor dan penetapan batas maritim Laut Timor secara permanen. Berdasarkan kesepakatan yang telah di tanda tangani oleh kedua belah pihak dalam pembagian hasil eksplorasi dari ladang minyak Greater Sunrise bahwa Timor Leste akan mendapat pembagian lebih besar dari Australia. Kesepakatan yang telah disepakati antara kedua belah pihak yang bersangkutan dalam pembagian Greater Sunrise, saat diskusi negosiasi di New York dijelaskan bahwa Timor Leste melakukan Rezim khusus untuk greater sunrise untuk eksplorasi pengembangan bersama dalam pengelolahan sumber daya alam yang saling menguntungkan. Kesepakatan yang dihasilkan untuk pembagian greater sunrise $70 \%$ pendapatan upstream masuk Timor Leste dan $30 \%$ ke Australia. Dan $80 \%$ operasi downstream dari Australia sedangkan $20 \%$ dari Timor Leste ${ }^{22}$

\section{Resolusi Konflik Australia Dan Timor Leste}

Konflik yang berkepanjangan pada permasalahan perbatasan maritim antara Australia dan Timor Leste yang berawal dari perairan laut Timor yang kaya dengan sumber minyak. Hal ini dapat dilihat berdasarkan Zona landas continental yang berada di laut Timor (celah Timor) yang kaya dengan sumber daya alamnya (minyak, gas, dan juga mineral) yang sangat melimpah. Seperti data yang didapat di ladang Laminaria dan Coranilla memiliki sekitar 250 juta bare $^{23}$. Untuk mengelolah hasil alam pada laut Timor tersebut, Timor Leste

\footnotetext{
${ }^{20}$ What's behind Timor-Leste terminating its maritime treaty with Australia", Theconversation, 10 Januari 2017

${ }^{21}$ Kate Mitchell dan Dapo Akande, "Espionage and Good Faith in Treaty Negotiations: East Timor v Australia" diunduh pada 18 Januari 2018

${ }^{22} \mathrm{https}$ //dfat.gov.au/geo/timor- leste/Documents/treaty-maritime- arrangements-australiatimor-leste.pdf

pada 1 juli 2019

${ }^{23}$ Neil William, "Oil and Gas Resources of Australia 2001", Geoscience Australia, (Australia,2002): iakses pada 16 Januari 2018
} 
mengadakan perjanjian yang ditujukan untuk pengelolahan dan pembagian hasil dari sumber daya alam tersebut. Dari berbagai perjanjian yang disepakati pertama tahun 2000 yaitu perjanjian Laut Timor, kedua perjanjian Unititasi untuk Greater Sunrise tahun 2003, Pejanjian terhadap maritim pada Laut Timor tahun 2006.Namun berdasarkan perjanjian tersebut pada tahun 2006 Australia melakukan pelanggraan atas kesepakatan yang telah di tentukan. Dan juga Australia memiliki niat buruk dengan menyadap pertemuan antara kabinet dan menteri dalam membahas pembagian ladang minyak di Celah Timor ${ }^{24}$.

Dengan demikian menjadi alasan bagi Timor Leste mengakhiri perjanjian tersebut. Hal ini dapat dilihat untuk kesekian kalinya diadakan pertemuan selama tahun 2016, akhirnya kedua negara yang bersangkutan menyetujui mengakhiri perjanjian tahun 2006 tentang batas maritime di laut Timor ${ }^{25}$. Kemudian di New York pada tanggal 6 maret 2018 Timor Leste dan Australia menandatangani kesepakatan guna menyelesaikan sengketa yang berlangsung lama terkait batas maritim serta pembagian hasil dari eksplorasi Greater Sunrise.

\section{KESIMPULAN}

Perbatasan wilayah merupakan zona yang berdampak sangat penting terhadap antar negara yang hidup bertetanggaan. Dari sudut perdamaian suatu negara yang bertetangga memiliki hubungan lintas batas yang baik yang dapat diterima oleh negara-negara yang bersangkutan. Dalam sudut pandang keamanan negara yang dapat melindungi atau mengontrol wilayahnya sendiri merupakan negara yang dapat dikatakan negara yang baik, namun bagi negara yang dikatakan gagal yaitu negara yang tidak dapat mengontrol atau melindungi negaranya sehingga penyusup atau teroris dapat masuk ke negara tersebut. Sedangkan dari sudut konflik internasional, kerap sering kali bahwa perbatasan wilayah menjadi konflik. Dari sudut konflik perbatasan internasional berkaitan dengan hubungan negara satu dengan dengan negara lain atau hubungan internasional. Penyebab konflik yang terjadi antar negara disebabkan adanya perbedaan pendapat antar negara yang bersangkutan. Salain perbedaan pendapat, penyebab konflik juga dapat terjadi dengan adanya batas wilayah hak milik yang melewati batas kepemilikan.

Usaha Timor Leste untuk mendapatkan kedaulatan nya dan apa yang menjadi hak miliknya, menuntut Timor Leste berjuang keras. Dalam pencapaian batas laut permanen dengan

\footnotetext{
${ }^{24}$ Jane Norman, "Australia and Timor-Leste Strike Deal to End Maritime Boundary Dispute”, News, 3 September 2017,

${ }^{25} \mathrm{https} / /$ www.woodside.com.au/our- business/timor-leste diakses pada tanggal

1 juli 2019
} 
Australia merupakan hal yang paling sulit. Dalam perebutan batas-batas hak miliknya demi mewujudkan kedaulatan yang penuh tanpa intervensi negara lain penuh aspirasi dalam pencapaiannya. Karena keberhasilan yang dilakukan Timor Leste ini membutuhkan butuh kesabaran yang signifikan dalam pencapaian tersebut. Serta tidak diragukaan lagi untuk memecahkan perselihan ini memerlukan cara-cara yang inovatif. Setelah melakukan berbagai perundingan negosiasi yang berkepanjangan dari tahun 2002-2016, akhirnya pada tanggal 6 maret 2018 di kantor PBB di New York Australia dan Timor Leste menanda tangani kesepakatan sebagai bentuk penyelesaian sengketa perbatasan di laut Timor dan penetapan batas maritim Laut Timor secara permanen. Berdasarkan kesepakatan yang telah di tanda tangani oleh kedua belah pihak dalam pembagian hasil eksplorasi dari ladang minyak Greater Sunrise bahwa Timor Leste akan mendapat pembagian lebih besar dari Australia. Kesepakatan yang telah disepakati antara kedua belah pihak yang bersangkutan dalam pembagian Greater Sunrise, saat diskusi negosiasi di New York dijelaskan bahwa Timor Leste melakukan Rezim khusus untuk greater sunrise untuk eksplorasi pengembangan bersama dalam pengelolahan sumber daya alam yang saling menguntungkan. Kesepakatan yang dihasilkan untuk pembagian greater sunrise $70 \%$ pendapatan upstream masuk Timor Leste dan $30 \% \mathrm{ke}$ Australia. Dan $80 \%$ operasi downstream dari Australia sedangkan $20 \%$ dari Timor Leste ${ }^{26}$

\section{SARAN}

Sebuah negara berhak melakuakn pertahanan dan kedaulatan sendiri guna untuk meningkatkan perekonomiannya sendiri. Setelah referendumnya Timor Leste dari Indonesia, sehingga sebagai negara termuda Timor Leste menyelesaikan permasalahan nya sendiri. Seperti halnya konflik perbatasan landasan kontinel dengan Australia.

Dalam penyelesaian masalah yang dialami oleh Timor Leste dengan Australia harus menerima keputasan dari PCA dari pengadilan Arbitase dan Timor leste mempunya batasa matirim permanen. Dan untuk wilayah greater sunrise sepakat untuk eksplorasi bersama.Dalam penyelesaian konflik perlu adanya kesepakatan antara kedua negara dan adanya pihak ketiga sebagai saksi.

\footnotetext{
${ }^{26} \mathrm{https}: / /$ dfat.gov.au/geo/timor- leste/Documents/treaty-maritime- arrangements-australia-timor-leste.pdf pada 1 juli 2019
} 


\section{DAFTAR PUSTAKA}

\section{Buku}

Mauna,Boer. 2003. Hukum Internasional, Pengertian, Peranan dan fungsi dalam dinamika global ed 1 cet 5 . Bandung :PT. Alumi

Roisah, kholis. 2015. Hukum Perjanjian Internasional (Teori dan Praktik). Malang: Setara Press.

Kusumaatmadja, Mochtar. 2015. Pengantar Hukum Internasional ed 2 cet 5. Bandung : PT.Alumni.

Subagyo, P. Joko, Hukum Laut Indonesia, (Jakarta: Rineka Cipta, 2009)

\section{Jurnal}

Darwin. "Tinjauan ulang minyak dan gas di Laut Timor". Buletin La'o Hamunutuk 4 (Agustus 2003): 2. Diakses pada 11 Oktober 2017, tersedia di: http://www.etan.org/lh/pdfs/bulletin/lhbl4n34bh.pdf

Andhika rahmadhoni' Asas Hukum Perjanjian Laut Timor ( CMAST) Antara Timor Leste dengan Australia dalam Perspektif Kajian Hukum Perjanjian Internasional Berdasarkan Konvensi 1969" vol 6 no 1 tahun 2017, Ponegoro Law Jurnal tersedia di: http://www.ejournal-s1.undip.ac.id/index.php/dlr/

Josefa Dos Santos Sarmento Barreto' 'Upaya Australia dan Timor-Leste dalam penyelesaian konflik Batas Maritim(kasus:Greater sunrise tahun2016-2018, Bandung 40132, Indonesia

Rizki Roza.’Penyelesaian Sengketa Celah Timor dan Implikasi Bagi Indonesia"vol 10 no 06 tahun 2018 info singkat bidang hubungan internasional tersedia di: http://berkas.dpr.go.id/puslit/files/info-singkat/info\%20singkat-X-6-II-P3DI-2018244.pdf

Maria M Niss "Strategi Timor Leste penyelesaian sengketa delimitasi laut timor" Universitas AirLangga tahun 2020 tersedia di: http://repository.unair.ac.id/96791/4/4.\%20BAB\%20I\%20PENDAHULUAN.pdf

\section{Website}

Australian Government Department of Foreign Affairs and Trade "Perjanjian Perencanaan Strategis untuk Pembangunan antara Pemerintah Timor Leste dan Pemerintah Australia." Department of Foreign Affairs and Trade.http://aid.dfat.gov.au/publications/document/strategic-planningagreement.pdf (accesed november 1,2011-reviewed March 3, 2016)

Australian Government Department of Foreign Affairs and Trade "Tinjauan Program Bantuan Australia untuk Timor Leste". Department of Foreign Affairs and Trade. http://aid.dfat.gov.au/countries/eastasia/timor/leste/pages/default.aspx (accesed 
December 16, 2014-reviewed April 28, 2016)

Australian Government Department of Foreign Affairs and Trade " hubungan bilateral dengan Timor Leste". Department of Foreign Affairs and Trade. http://www.dfat.gov.au/geo/timor-leste

Dwi Nicken Tari "porsi pendapatan timor leste di blok greater sunrise aakan lebih besar".bisnis.com.

https://www.google.com/amp/s/m/bisnis.com/amp/read/20180307/19/747373/pors i-pendapatan-timor-leste-di-blok-greater-sunrise-akan-lebih-besar

Rebecca Starting Universitas La Trobe “ apa yang melatarbelakangi Timor-Leste mengakhiri Perjanjian Maritimnya dengan Australia”.The Conversation. http://theconvesation.com/whats-behind-timor-leste-terminating-its-maritime-treatyaustralia-71002 (accesed Januari 10, 2017) 